\title{
PENGARUH E-SERVQUAL TERHADAP E-SATISFACTION, E-WOM DAN ONLINE REPURCHASE INTENTION
}

\author{
Saodin \\ Program Studi Manajemen, STIE Muhammadiyah Kalianda \\ saodin@gmail.com
}

\begin{abstract}
Abstrak
Penelitian ini secara spesifik bertujuan untuk menguji dan menjelaskan pengaruh $e$-service quality terhadap $e$-satisfaction, $e$-word of mouth dan online repurchase intention konsumen pada Hotel Bintang Tiga di Provinsi Lampung. Penelitian ini bersifat explanatory research yang menjelaskan hubungan kausal antara variabel melalui pengujian hipotesis. Jumlah sampel dalam penelitian ini 142 konsumen hotel yang pernah menginap dan melakukan reservasi (pemesanan kembali) secara online melalui website pemesanan hotel di salah satu Hotel Bintang Tiga di Provinsi Lampung. Teknis analisis data menggunakan analisis Generalized Structured Component Analysis (GSCA). Temuan penelitian menunjukan bahwa lima hipotesis yang diajukan diterima yang bermakna terdapat pengaruh yang signifikan e-service quality terhadap $e$-satisfaction, $e$-word of mouth dan online repurchase intention.
\end{abstract}

Kata kunci: E-ServQual; E-Satisfaction; E-WOM; Online Repurchase Intention

\section{PENDAHULUAN}

Industri perhotelan dalam perkembangannya telah menjadi suatu industri global dan semakin menunjukkan kematangan, karena itu industri perhotelan dihadapkan dengan persaingan yang ketat untuk mempertahankan tingkat pertumbuhannya (Kandampully and Suhartanto, 2000). Tantangan yang muncul adalah bagaimana menyediakan layanan yang kompetitif di perusahaan secara menyeluruh, yang semakin memungkinkan setiap bagian di dalam perusahaan mampu bekerja secara lebih efisien dan produktif, yang akhirnya mendorong peningkatkan pelayanannya kepada pelanggan. Artinya, perusahaan harus mampu memberikan pelayanan secara efisien dan efektif, yang benar-benar dapat memenuhi kebutuhan konsumen.

Kualitas layanan yang dirasakan dan diperlukan konsumen tidak hanya pada saat menginap dengan ketersediaan segala fasilitas hotel, akan tetapi diawali setiap konsumen melakukan pencarian informasi tentang hotel dan ketersediaan kamar pada hotel. Kondisi tersebut mengharuskan pengelola hotel menyediakan fasilitas 
informasi yang lengkap tentang hotel, agar konsumen mudah mendapatkan informasi. Penyediaan informasi tentang hotel salah satunya dapat dilakukan melalui pemanfaatan teknologi informasi internet dengan menyedikan website yang di dalamnya terdapat informasi yang lengkap tentang hotel.

Aksu and Tarcan (2002) menyatakan bahwa pada tahun 1995 pembuatan website dalam industri perhotelan pertama kali ditujukan untuk hotel bintang lima. Dari studi yang dilakukan tersebut, didapatkan kesimpulan bahwa industri perhotelan menggunakan website sebagai saluran komunikasi dua arah, dimana website selain sebagai sarana untuk memperkenalkan produk jasa hotel dan mendapatkan konsumen baru, juga sebagai sarana bagi konsumen untuk berkomunikasi dengan pihak hotel. Menurut Jeong and Lambert (2001) pembuatan website suatu hotel harus mempertimbangkan prilaku dari konsumen, tidak hanya atribut dan dimensi dalam website sehingga tujuan website sebagai alat pemasaran tercapai. Performa website suatu hotel dapat diukur dari isi website tersebut dan investigasi persepsi pengguna website

Berdasarkan kondisi tersebut, untuk meningkatkan layanannya, beberapa hotel membuat website untuk memudahkan konsumen untuk melakukan reservasi (pemesanan). Hal ini mendukung penelitian yang dilakukan oleh Zeithaml and Bitner (2006), yang menyatakan bahwa persepsi pelanggan terhadap kualitas layanan dari produk atau jasa merupakan faktor utama yang mempengaruhi kepuasan. Kualitas layanan yang unggul demi tercapainya kepuasan pelanggan merupakan faktor kunci utama dalam memenangkan persaingan. Chase, Jacobs, and Aquilano (2006) meyatakan bahwa e-service quality atau yang juga dikenal sebagai e-servqual merupakan versi baru dari service quality (servqual). E-servqual, dikembangkan untuk mengevaluasi suatu pelayanan yang diberikan pada jaringan internet. E-service quality didefinisikan sebagai perluasan dari kemampuan suatu situs untuk memfasilitasi kegiatan belanja, pembelian, dan distribusi secara efektif dan efisien.

Menurut Kotler (2009) kepuasan merupakan fungsi dari kinerja yang dirasakan (perceived performance) dan harapan (expectations). Apabila kinerja produk atau jasa lebih rendah dari harapan, konsumen merasa tidak puas. Jika kinerja sesuai harapan maka konsumen merasa puas, jika kinerja sampai melebihi 
harapan, maka konsumen merasa sangat puas (delighted). Kepuasan pelanggan online dan tradisional pada umumnya tidak berbeda jauh.

Sabiote et al. (2012) menyatakan kualitas layanan dianggap sebagai suatu strategi penting untuk berhasil di lingkungan yang kompetitif saat ini. E-service quality yang baik menimbulkan kepuasan kepada pelanggan, mengingat berdasarkan literatur yang ada menunjukkan bahwa kepuasan dengan media elektronik itu akan ditentukan oleh kualitas yang dirasakan dari e-service. Kemampuan industri perhotelan dalam memberikan layanan online yang berkualitas akan mampu meningkatkan kepuasan konsumen, hal ini diperkuat oleh Swaid and Wigand (2007) yang menyatakan bahwa dengan memberikan kualitas layanan atau e-servqual yang superior, maka kepuasan dan loyalitas pelanggan akan semakin meningkat.

Menurut Lee and Lin (2011) dalam penelitiannya menjelaskan perusahaan yang sudah memiliki pengalaman dalam menggunakan media internet dalam kegiatan pemasarannya harusnya mulai menyadari bahwa kunci yang menentukan kegagalan atau kesuksesan bukan hanya dari sisi kualitas webiste atau harga yang murah saja tetapi kualitas service yang diberikan perusahaan yang merupakan faktor penting kesuksesan. E-Service quality yang baik dan sesuai dengan yang diinginkan oleh konsumen rnembuktikan bahwa perusahaan tersebut berorientasi kepada konsumen. Perusahaan tersebut berusaha untuk memahami keinginan konsumennya yakni dengan meningkatkan customer satisfaction.

Indikasi bahwa konsumen yang puas menjadi loyal adalah melalui upaya penggunaan ulang (repurchase intention) menunjukkan kesetiaan (loyalty) dan atau memberikan rekomendasi positif (positive WOM) sesuai dengan pernyataan Kurtz and Clow (1998). Sarana promosi gratis melalui positive word of mouth mampu meningkatkan kepuasan, di mana konsumen yang merasa puas merekomendasi layanan online tersebut kepada rekan kerja dan masyarakat sekitar. Konsumen yang puas secara sukarela mengajak konsumen lain untuk menggunakan layanan online.

Penelitian yang dilakukan oleh Moningka and Loindong (2016) menemukan bahwa service scape berpengaruh positif dan signifikan terhadap keputusan pembelian. Menurut Parastanti, Srikandi, dan Kadarisman (2014), online repurchases intention merupakan situasi dimana konsumen berkeinginan dan berniat untuk kembali membuat transaksi online. Transaksi online yang dimaksud adalah 
suatu kegiatan dimana proses pencarian informasi, transfer informasi, dan pembelian produk terjadi secara online.

Bulut (2015) meyatakan bahwa repurchase intention merupakan keputusan individu tentang pembelian kembali layanan yang dipilih dari perusahaan yang sama, dengan mempertimbangkan keadaan individu tersebut. Keadaan individu yang dimaksud adalah kepuasan yang dirasakan oleh pembeli atas pembelian tersebut. E-satisfaction, dan e-wom, mempengaruhi secara positif dan signifikan terhadap online repurchase intention. Repurchase intention penting bagi perusahaan karena konsumen yang bersedia membeli kembali pada perusahaan merupakan aset yang penting, sehingga penting bagi setiap perusahaan yang bergerak dibisnis $e$ commerce, untuk memastikan bahwa konsumen akan kembali membeli barang atau produk dari perusahaan tersebut dikemudian hari (Gefen, 2002; and Zhou et al., 2009).

Mengacu pada beberapa hasil penelitian terdahulu dan teori yang ada, penelitian ini berusaha mengembangkan model yang lebih representatif dari masing masing variabel yang diidenntifikasi sebagai varaibel yang memiliki pengaruh terhadap online repurchase intention. Lebih lanjut, penelitian bertujuan untuk menguji dan menjelaskan pengaruh $e$-service quality terhadap e-satisfaction, $e$ word of mouth dan online repurchase intention pada Hotel Bintang Tiga di Provinsi Lampung dengan mengembangkan sebuah model penelitian, disajikan dalam Gambar 1.

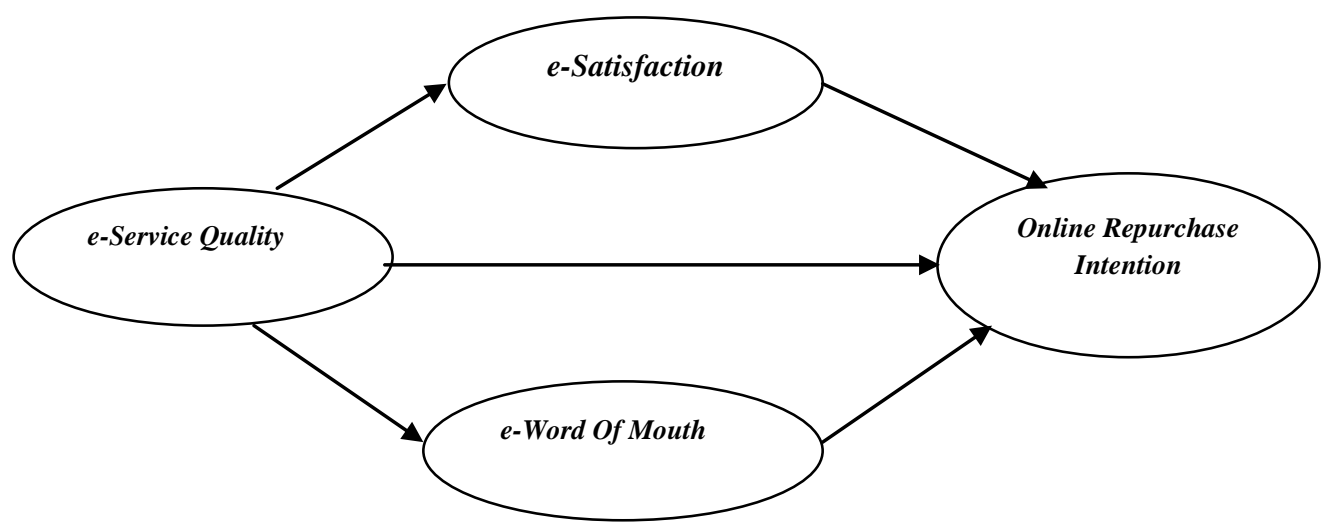

Gambar 1. Model Penelitian 
Tabel 1. Hipotesis, Referensi Teori dan Penelitian Terdahulu

\begin{tabular}{|c|c|c|c|c|c|}
\hline \multirow{2}{*}{ Hipotesis } & \multirow{2}{*}{ Path } & \multicolumn{3}{|c|}{ Path Coefficients } & \multirow{2}{*}{-Keterangan } \\
\hline & & Estimate & SE & $\mathbf{C R}$ & \\
\hline H1 & $\begin{array}{l}e \text {-Service Quality } \rightarrow \\
\text { e-Satisfaction }\end{array}$ & 0.816 & 0.014 & $59.87 *$ & Signifikan \\
\hline $\mathrm{H} 2$ & $\begin{array}{l}\text { e-Service Quality } \rightarrow \text { e-word of } \\
\text { mouth }\end{array}$ & 0.538 & 0.149 & $3.62 *$ & Signifikan \\
\hline $\mathrm{H} 3$ & $\begin{array}{l}e \text {-Service Quality } \rightarrow \text { Online } \\
\text { Repurchase Intention }\end{array}$ & 0.138 & 0.040 & $3.48^{*}$ & Signifikan \\
\hline $\mathrm{H} 4$ & $\begin{array}{l}\text { e-Satisfaction } \rightarrow \text { Online Repurchase } \\
\text { Intention }\end{array}$ & 0.382 & 0.034 & $11.18 *$ & Signifikan \\
\hline H5 & $\begin{array}{l}\mathrm{e}-\text { word of mouth } \rightarrow \text { Online } \\
\text { Repurchase Intention }\end{array}$ & 0.233 & 0.050 & $4.62 *$ & Signifikan \\
\hline
\end{tabular}

\section{METODE PENELITIAN}

Penelitian ini menggunakan pendekatan kuantitatif dengan jenis penelitian explanatory research yang dilakukan untuk menjelaskan hubungan kausal antara variabel-variabel penelitian melalui pengujian hipotesis. Sampel dalam penelitian sebanyak 142 konsumen hotel yang pernah menginap di salah satu Hotel Bintang Tiga di Provinsi Lampung dengan kriteria; a) Konsumen yang melakukan reservasi (pemesanan kembali) secara online melalui website pemesanan hotel, b) Berusia sama atau lebih dari 17 tahun. c) Pernah menginap lebih dari 1 (satu) kali pada salah satu Hotel Bintang Tiga di Provinsi Lampung.

Proses pengumpulan data menggunakan instrumen dengan media survey google forms melalui link yang disebarkan melalui personal chat maupun dibagikan pada grup virtual dengan skala Likert 5 pilihan jawaban mulai dari sangat tidak setuju (skor 1) sampai dengan sangat setuju (skor 5). Teknik analisis data menggunakan Generalized Structured Component Analysis (GSCA) dengan software GeSCA. Penggunaan GSCA didasari penggunaan sampel yang kecil, selain itu, pada metode GSCA, data tidak harus berdistribusi normal (distribution free), tidak mengasumsikan data berdistribusi tertentu dan skala nominal, ordinal, interval dan rasio dapat digunakan pada model yang sama (Solimun, 2013). 


$\begin{array}{ll}\text { ISSN Cetak } & : 2087-0434 \\ \text { E-ISSN } & : 2599-0810\end{array}$

Penelitian ini menggunakan empat variabel yang terdiri satu variabel endogen dan 3 variabel eksogen, dapat dilihat dari table berikut:

Tabel 2. Pengukuran Variabel

\begin{tabular}{|c|c|c|}
\hline Variabel & Indikator & Sumber \\
\hline $\begin{array}{l}\text { e-Service Quality } \\
\text { (X) }\end{array}$ & $\begin{array}{l}\text { 1) Tampilan website hotel menarik } \\
\text { 2) Kemudahan menggunakan website hotel } \\
\text { 3) Kesesuaian informasi website hotel } \\
\text { 4) Website hotel mempunyai fungsi teknis yang benar } \\
\text { 5) Website hotel memberikan rasa aman untuk } \\
\text { perlindungan konsumen } \\
\text { 6) Kehandalan Website hotel dalam pemberian } \\
\text { layanan } \\
\text { 7) Kehandalan operator Website hotel dalam } \\
\text { memecahkan masalah konsumen } \\
\text { 8) Empaty operator kepada konsumen }\end{array}$ & $\begin{array}{l}\text { Parasuraman et al. } \\
\text { (2005); } \\
\text { Kotler and Keller } \\
\text { (2012); } \\
\text { Ribbink et al. } \\
\text { (2004) dan } \\
\text { Zeithaml } \text { et. al. } \\
\text { (2013) }\end{array}$ \\
\hline $\begin{array}{l}\text { E-Satisfaction } \\
\text { (Y1) }\end{array}$ & $\begin{array}{l}\text { 1) Puas dengan reservasi website hotel } \\
\text { 2) Puas dengan keputusan reservasi dari website hotel } \\
\text { 3) Puas dengan pengalaman reservasi di website hotel } \\
\text { 4) Puas secara keseluruhan dengan website }\end{array}$ & $\begin{array}{l}\text { Fang et al. (2011); } \\
\text { Oliver (1997); } \\
\text { Anderson and } \\
\text { Srinivasan, 2003); }\end{array}$ \\
\hline$E-W O M(Y 2)$ & $\begin{array}{l}\text { 1) Berinteraksi dengan rekan rekan pad website hotel } \\
\text { 2) Berbagi gambar/teks ke website hotel } \\
\text { 3) Berbagi informasi hotel tempat menginap di web } \\
\text { site } \\
\text { 4) Berbagi untuk mengungkapkan perasaan melalui } \\
\text { website hotel } \\
\text { 5) Berbagi pengalaman reservasi hotel di website } \\
\text { hotel }\end{array}$ & $\begin{array}{l}\text { Hennig-Thurau et } \\
\text { al. (2004). }\end{array}$ \\
\hline $\begin{array}{l}\text { Online } \\
\text { Repurchase } \\
\text { Intention (Y3) }\end{array}$ & $\begin{array}{l}\text { 1. Akan terus reservasi online di website hotel } \\
\text { 2. Akan mengajak orang lain untuk reservasi online di } \\
\text { website hotel } \\
\text { 3. Akan menggunakan website hotel ini untuk } \\
\text { reservasi online } \\
\text { 4. Lebih memilih menggunakan website hotel } \\
\text { daripada reservasi manual/ tradisional } \\
\text { 5. Akan mengunjungi lagi website hotel ini di masa } \\
\text { depan }\end{array}$ & $\begin{array}{l}\text { Bulut et al. (2015); } \\
\text { Ferdinand (2002); } \\
\text { Zhou et al.(2009); } \\
\text { Kim et al. (2012). }\end{array}$ \\
\hline
\end{tabular}

\section{HASIL DAN PEMBAHASAN}

Evaluasi model struktural bertujuan mengetahui measure of fit, yaitu; seberapa besar informasi yang dapat dijelaskan oleh model struktural (hubungan antar variabel) hasil analisis GSCA (Generalized Structured Component). Goodness of fit model struktural diukur menggunakan FIT dan AFIT. FIT menunjukkan varian total dari semua variabel yang dapat dijelaskan oleh model struktural. Nilai FIT berkisar dari 0 sampai 1 , semakin besar nilainya maka semakin besar variabel dapat 
ISSN Cetak : :2087-0434

E-ISSN : :2599-0810

dijelaskan oleh model (Solimun, 2013). Oleh karena nilai FIT biasanya berpengaruh terhadap kompleksitas model, sehingga perlu adanya AFIT (adjusted FIT). Hasil analisis tentang FIT adan AFIT model penelitian disajikan dalam Tabel berikut:

Tabel 3. Evaluasi Model Struktural

\begin{tabular}{lll}
\hline $\begin{array}{l}\text { Kriteria } \\
\text { Measure of fit }\end{array}$ & Nilai Indeks & Keterangan \\
\hline FIT & 0.542 & Model Good Fit \\
\hline AFIT & 0.534 & Model Good Fit \\
\hline
\end{tabular}

Hasil analisis menunjukkan nilai FIT sebesar 0.542, Ini berarti model yang terbentuk mampu menjelaskan semua variabel yang ada sebesar 54,2\%. Nilai AFIT $=$ 0.534 menunjukkan keragaman variabel e-service quality, e-satisfaction, e-wom, terhadap online repurchase intention yang dapat dijelaskan oleh model setelah mengalami koreksi adalah sebesar 53.4\%. Pengujian hipotesis pada analisis GSCA didasarkan pada nilai estimate dan signifikansi antar variabel. Hasil pengujian disajikan dalam Tabel 4.

Tabel 4. Hasil Analisis Pengujian Hipotesis

\begin{tabular}{|c|c|c|c|c|c|}
\hline \multirow{2}{*}{ Hipotesis } & \multirow{2}{*}{ Path } & \multicolumn{3}{|c|}{ Path Coefficients } & \multirow{2}{*}{-Keterangan } \\
\hline & & Estimate & SE & $\mathbf{C R}$ & \\
\hline $\mathrm{H} 1$ & $\begin{array}{l}e \text {-Service Quality } \rightarrow \\
\text { e-Satisfaction }\end{array}$ & 0.816 & 0.014 & $59.87 *$ & Signifikan \\
\hline $\mathrm{H} 2$ & $\begin{array}{l}\text { e-Service Quality } \rightarrow \text { e-word of } \\
\text { mouth }\end{array}$ & 0.538 & 0.149 & $3.62 *$ & Signifikan \\
\hline H3 & $\begin{array}{l}\text { e-Service Quality } \rightarrow \text { Online } \\
\text { Repurchase Intention }\end{array}$ & 0.138 & 0.040 & $3.48 *$ & Signifikan \\
\hline $\mathrm{H} 4$ & $\begin{array}{l}\text { e-Satisfaction } \rightarrow \text { Online Repurchase } \\
\text { Intention }\end{array}$ & 0.382 & 0.034 & $11.18 *$ & Signifikan \\
\hline H5 & $\begin{array}{l}\text { e-word of mouth } \rightarrow \text { Online } \\
\text { Repurchase Intention }\end{array}$ & 0.233 & 0.050 & $4.62 *$ & Signifikan \\
\hline
\end{tabular}

Hasil pengujian hipoteisis menunjukkan bahwa, e-service quality berpengaruh positif dan signifikan terhadap e-satisfaction. Dengan demikian dapat disimpulkan bahwa semakin baik e-service quality akan mengakibatkan $e$ satisfaction semakin meningkat. Makna dari temuan ini menunjukkan bahwa secara empiris e-service quality merupakan faktor penentu dalam e-satisfaction pada Pengguna Jasa yang melakukan reservasi secara online pada Hotel Bintang Tiga di Provinsi Lampung. Kemampuan situs web hotel dalam pemberian layanan dengan 
tepat, kompetensi operator dalam menangani permasalah pengguna jasa, serta empaty operator pada pengguna jasa.

Hasil penelitian ini sejalan dengan teori yang menyatakan bahwa e-service quality merupakan hasil dari proses evaluasi dimana harapan pelanggan dibandingkan dengan layanan yang dirasakan atau yang telah diterima. Hasil penelitian ini juga mendukung pendapat Parasuraman, et al. (1988) yang memanfaatkan model SERVQUAL untuk mengukur persepsi dan harapan pelanggan,yang mana hasil pengukuran ini menentukan tingkat kepuasan pelanggan (Parasuraman et al. 1988)..

Temuan penelitian ini menunjukkan bahwa e-service quality mempengaruhi kepuasan pelanggan dalam melakukan reservasi secara online. Saat pelanggan akan melakukan reservasi online, apabila website hotel memiliki fungsi teknis yang mudah digunakan serta informasi dan layanan yang tepat maka pelanggan akan merasa puas terhadap layanan yang diberikan website hotel tersebut.

E-service quality terbukti berpengaruh signifikan terhadap e-word of mouth. Makna dari itu, temuan ini menunjukkan bahwa secara empiris e-service quality merupakan faktor penentu e-word of mouth pada Pengguna Jasa yang yang melakukan reservasi secara online pada Hotel Bintang Tiga di Provinsi Lampung. Temuan ini juga mengindikasikan bahwa $e$-word of mouth pengguna jasa yang melakukan reservasi secara online pada Hotel Bintang Tiga di Provinsi Lampung selalu ditentukan oleh indikator tampilan website hotel, kemudahan pengguna jasa menggunakan website, kesesuaian informasi website, website hotel mempunyai fungsi teknis yang benar, website hotel memberikan rasa aman untuk pengguna jasa, kemampuan website hotel dalam pemberian layanan dengan tepat, kompetensi operator dalam menangani permasalah pengguna jasa, serta empaty operator pada pengguna jasa.

Temuan penelitian ini mengkonfirmasi dan memperluas konsep Gronroos (2000); Keller (1993) yaitu; e-service quality yang berkualitas akan meninggalkan kesan positif yang tertanam dibenak pelanggan. Kesan positif ini selanjutnya akan membentuk persepsi tentang $e$-word of mouth yang bersangkutan. Sikap pelanggan terhadap e-service quality merupakan fungsi dan aktivitas awal ketika membeli dan mendapatkan e-word of mouth ketika reservasi. Pelanggan akan memiliki sikap 
positif atau image yang baik tentang penyedia jasa website hotel apabila telah memperoleh layanan yang memuaskan sebelumnya.

Temuan penelitian ini mendukung hasil penelitian yang dilakukan oleh Wang et al. (2003) dan Alireza et al. (2011). E-WOM adalah persepsi tentang suatu informasi dari mulut ke mulut/getok tular yang tertanam dibenak pelanggan dan bekerja sebagai penyambung informasi yang memengaruhi persepsi tentang website suatu hotel.

E-Service quality berpengaruh positif dan signifikan terhadap online repurchase intention, dengan demikian terdapat dukungan untuk menerima hipotesis yang menyatakan bahwa "e-service quality berpengaruh terhadap online repurchase intention". Nilai koefisien bertanda positif mengandung arti bahwa semakin baik $e$ service quality akan mengakibatkan online repurchase intention juga semakin meningkat.

Kualitas layanan elektronik (e-service quality) merupakan strategi penting dalam pemasaran secara online. Dalam penjualan online, kualitas layanan yang baik mampu menciptakan kepuasan, kepercayaan serta mempertahankan keunggulan kompetitif dalam usaha. Ini merupakan salah satu faktor penting dalam mempertahankan hubungan jangka panjang dengan pelanggan. Layanan pada website hotel yang bagus, informatif, mudah digunakan, mampu membuat pelanggan untuk melakukan pembelian ulang. Oleh karena itu, kualitas layanan telah menjadi faktor penting dalam menentukan keberhasilan atau kegagalan bisnis online dengan memengaruhi pengalaman belanja pelanggan online dan memiliki efek yang sangat besar pada pembelian kembali.

Temuan penelitian ini menunjukkan bahwa menciptakan dan mengembangkan online repurchase intention membutuhkan proses yang cukup panjang sehingga memerlukan waktu yang lama, mulai dari pembelian pertama kali (first time buyer) dan sampai pada tahap selanjutnya melakukan online repurchase intention serta pelanggan yang bisa membujuk/ memengaruhi pelanggan lainnya.

Temuan ini juga mengindikasikan bahwa online repurchase intention pengguna jasa yang melakukan reservasi secara online pada Hotel Bintang Tiga di Provinsi Lampung selalu ditentukan oleh indikator e-satisfaction yang meliputi puas dengan hasil reservasi di website hotel, puas dengan keputusan reservasi yang 
dilakukan, puas dengan reservasi dari website hotel, puas dengan pengalaman reservasi serta puas secara keseluruhan dengan website hotel.

Hasil penelitian ini sejalan dengan teori yang menyatakan bahwa $e$ satisfaction merupakan hasil dari proses evaluasi dimana harapan pelanggan dibandingkan dengan layanan yang dirasakan atau yang telah diterima. Hasil penelitian ini juga mendukung pendapat Parasuraman et al. (1988) yang memanfaatkan model SERVQUAL untuk mengukur parsepsi dan harapan pelanggan, yang mana hasil pengukuran ini menentukan tingkat kepuasan pelanggan.

Makna dari temuan ini menunjukkan bahwa secara empiris $e$-word of mouth merupakan faktor penentu online repurchase intention pada Pengguna Jasa yang yang Melakukan Reservasi secara online pada Hotel Bintang Tiga di Provinsi Lampung. Temuan ini juga mengindikasikan bahwa online repurchase intention pengguna jasa yang yang melakukan reservasi secara online pada Hotel Bintang Tiga di Provinsi Lampung selalu ditentukan oleh indikator $e$-word of mouth yang meliputi berinteraksi dengan rekan rekan di website hotel, Berbagi gambar/teks ke website hotel, Berbagi informasi hotel tempat menginap di website, berbagi mengungkapkan perasaan melalui website dan berbagi pengalaman reservasi hotel.

Temuan penelitian ini mengkonfirmasi dan memperluas teori Word of Mouth yang mana komunikasi dari mulut ke mulut adalah salah satu cara tertua untuk menyampaikan informasi (Dellarocas, 2003). Menurut Katz and Lazarsfeld (1955) Word of Mouth menggambarkan suatu pertukaran informasi pemasaran antara konsumen sedemikian rupa sehingga memainkan peran mendasar dalam membentuk perilaku mereka dan dalam mengubah sikap terhadap produk dan layanan. Matute, Polo-Redondo and Utrillas (2016) mengemukakan bahwa WOM adalah alat komunikasi orang-ke-orang antara komunikator dan penerima, yang menganggap informasi yang diterima tentang suatu merek, produk atau layanan. Lebih lanjut Litvin et al. (2008) menyatakan word of mouth merupakan komunikasi antara konsumen tentang suatu produk, layanan atau perusahaan di mana sumbersumbernya dianggap independen dari pengaruh komersial. 


\section{KESIMPULAN}

Temuan penelitian secara keseluruhan menunjukkan bahwa 5 hipotesis yang diajukan dalam penelitian ini diterima. E-service quality berpengaruh signifikan terhadap e-satisfaction. Artinya semakin tinggi e-service quality yang didapatkan oleh pelanggan akan semakin meningkatkan e-Satisfaction pelanggan dalam melakukan pemesanan kembali secara online. E-service quality berpengaruh signifikan terhadap $e$-word of mouth. Artinya semakin tinggi $e$-service quality yang didapatkan oleh pelanggan maka mampu meningkatkan $e$-word of mouth pelanggan kepada konsumen lainnya.

E-service quality berpengaruh signifikan terhadap online repurchase intention. Artinya semakin meningkat e-service quality maka semakin meningkat online repurchase intention. Konsumen akan melakukan online repurchase intention apabila didukung oleh pemberian e-service quality dari aplikasi website pemesanan hotel secara online yang memiliki fasilitas fisik menarik, handal, memiliki daya tanggap terhadap konsumen, mampu menumbuhkan rasa percaya pada pelanggan, memberikan perhatian yang bersifat individual atau pribadi kepada pelanggan, kemampuan website pemesanan hotel secara online memberikan informasi kepada konsumen, keberhasilan website pemesanan hotel secara online dalam menyampaikan informasi dan situs berfungsi untuk melayani konsumen sebagaimana mestinya.

E-satisfaction berpengaruh signifikan terhadap online repurchase intention. Artinya semakin meningkat e-satisfaction maka semakin meningkat online repurchase intention. Hal ini dimungkinkan karena bagi konsumen yang memiliki tingkat kepuasan yang tinggi cenderung untuk tetap berhubungan dengan website hotel karena merasa nyaman, aman dan tidak dirugikan. Konsumen yang puas inilah yang mempunyai kecenderungan untuk melakukan pembelian ulang dan merekomendasikan barang atau jasa.

E-word of mouth berpengaruh signifikan terhadap online repurchase intention. Artinya semakin meningkat $e$-word of mouth maka semakin meningkat online repurchase intention. Dengan kata lain, semakin positif $e$-word of mouth maka akan menimbulkan minat pembelian ulang konsumen pada website hotel. 


ISSN Cetak : : 2087-0434

E-ISSN $\quad: 2599-0810$

\section{DAFTAR REFERENSI}

Aksu, A.A., and Tarcan, E. 2002. "The Internet and five star hotels: A case study from the Antalya region in Turkey". International Journal of Contemporary Hospitality Management, 14 (2): 94-97. DOI: 10.1108/ 09596110210419 282.

Alireza, F., Ali, K., and Aram, F. 2011. "How Quality, Value, Image, and Satisfaction Create Loyalty at an Iran Telecom". International Journal of Business and Management, 6 (8): 271-281.

Anderson, R. E., and Srinivasan, S. S. 2003. "E-Satisfaction and e-loyalty: a contingency framework”. Psychology and Marketing, 20 (2): 123-138.

Arasli, H., Mehtap-Smadi, A., Katircioglu, A.T. 2005. "Customer Service Quality in the Greek Cypriot Banking Industry”. Managing Service Quality, 15:41-56.

Bulut, A. Z. 2015. "Determinants of repurchase intention in online shopping: a Turkish consumer's perspective". International Journal of Business and Social Science, 6 (10): 55-63.

Butt, M.M., and Aftab,M. 2013. "Incorporating attitude towards Halal banking in an integrated service quality, satisfaction, trust and loyalty model in online Islamic banking context". International Journal of Bank Marketing, 31 (1): 6-23.

Cerri, Shpetim. 2012. "Exploring the Relationships among Service Quality, Satisfaction, Trust and Store Loyalty among Retail Customers". Journal of Competitiveness, 4 (4): 16-35. DOI:10.7441/joc.2012.04.02.

Chamcuntra, S., and Fongsuwan, W. 2014. "Customer repurchase intention, trust and customer satisfaction influencing outsourced employees at kasikornbank bank publict company limites (Thailand)". International Journal of Arts and Sciences, 7 (3): 233-242.

Chase, R. B., Jacobs, F. R., and Aquilano, N. J. 2006. Operations Management for Competitive Advantage. 11th Ed. New York: McGraw Hill.

Chase, M.E. 2006. Identity Development And Body Image Dissatisfaction Action In College Females. University Of Wisconsin.

Cyr, D. 2008. "Modeling Website Design Across Cultures: Relationship to Trust, Satisfaclion, and E-Ioyalty". Journal of Management Information Systems, 24 (4): 47-72.

Dabholkar, P.A., Shepherd, C.D., and Thorpe, D.I. 2000. “A Comprehensive Framework for Service Quality: An Investigation of Critical Conceptual and Measurement Issues Through a Longitudinal Study". Journal of Retailing, 76 (2): 139-173. 


ISSN Cetak : : 2087-0434

E-ISSN $\quad: 2599-0810$

Dellarocas, C. 2003. "The Digitization of Word-of-Mouth: Promise and Challenges of Online Feedback Mechanisms" (March 2003). MIT Sloan Working Paper No. 429603. Available at SSRN: https://ssrn.com/abstract=393042.

East, R., Hammond, K., and Lomax, W. 2008. "Measuring the impact of positive and negative word of mouth on brand purchase probability". International Journal of Research in Marketing. 25 (3), 215-224.

Fang, Y. H., Chiu, C.M., and Wang, E.T. 2011. "Understanding cus-tomers' satisfaction and repurchase intentions: An integration of IS success model, trust, and justice". Internet Research, 21 (4): 479-503.

Ferdinand, A. 2002. Metode Penelitian Manajemen: Pedoman Penelitian untuk skripsi, Tesis dan Disertai Ilmu Manajemen. Semarang: Universitas Diponegoro.

Flavian, C., Guinaliu, M., and Gurrea, R. 2006. "The Role Playedby Perceived Usability, Satisfaction and Consumer Trust onWebsite Loyalty". Information and Management (43): 1-14.

Gefen, D. 2002. "Customer Loyalty in E-Commerce". AIS Educator Journal, 3 (1): 27-51. DOI: $10.17705 / 1$ jais.00022.

Goyette, I., Richard, L., Bergeron, J., and Martictte. F. 2012. "E-WOM scale: Word-ofmouth measurement scale for eservice context". Canadian Journal of Administrative Sciences, 27 (1): 5-23.

Gruen, T., Osmonbekov, T., and Czaplewski, A.J. 2006. "e-WOM: The impact of customerto-customer online know-how exchange on customer value and loyalty". Journal of Business Research, 59 (4): 449-456.

Hennig-Thurau, T., Gwinner, K.P., Walsh, G., and Gremler, D.D. 2004. "Electronic word of mouth via Consumer-Opinion Platforms: What motivates customer articulation themselves on the internet?". Journal of Interactive Marketing, 18 (1): 38-52. DOI: 10.1002/dir.10073.

Grönroos, C., Helnomen, F., Isoniemi. K, and Lindholm, M. 2000. "The Net Offer model: A case example from the virtual marketspace". Management Decision, 38 (4): 243252.

Hume, M., and Mort, G.S. 2010. "The consequence of appraisal emotion, service quality, perceived value and customer satisfaction on repurchase intent in the performing arts”. Journal of Services Marketing, 24(2): 170-182. http://dx.doi.org/10.1108/08876041011031136. 


ISSN Cetak : : 2087-0434

E-ISSN $\quad: 2599-0810$

Jalilvand, M.R., Samiei, N., Dini, B., and Manzari, P.Y. 2012. "Examining the Structural Relationships of E-Word of Mouth, Destination Image, Tourist Attitude Toward Destination and Travel Intention: An Integrated Approach". Journal of Destination Marketing \& Management, 1 (1-2): 134-143. https://doi.org/10.1016/j.jdmm. 2012.10.001.

Jeong, M., and Lambert, C.U. 2001. "Adaptation of an information quality framework to measure customers' behavioral intentions to use lodging Web sites". International Journal of Hospitality Management, 20(2): 129-146. DOI: 10.1016/S02784319(00)00041-4.

Kandampully, J and Suhartanto, D. 2000. "Customer loyalty in the hotel industry, the role of customer satisfaction and image", International Jurnal of Contemporary Hospitality Management, 12 (16): 346-351.

Kassim, N., and Abdullah, N.A. 2010. "The effect of perceived service quality dimensions on customer satisfaction, trust, and loyalty in e-commerce settings: a cross cultural analysis". Asia Pacific Journal of Marketing and Logistics, 22(3):51-371. DOI:10.1108/13555851011062269.

Katz, E., and Lazarsfeld, P. F. 1955. Personal influence: The part played by people in theflow of mass communication. Glencoe, IL: Free Press.

Keller, K.L. 1993. Strategic brand management: Building, measuring, and managing brand equity, 3rd edition. Harlow Upper Saddle River, N.J.: Prentice Hall.

Kim, J., Jin, B., and Swinney, J.L. 2009. "The role of etail quality, e-satisfaction, and e-trust in online loyalty development process". Journal of Retailing and Consumer Services, 16: 239-247.

Kim, S.H., Singh, A.J., and Yoon, S. 2012. "Evaluating applicability of e-service quality in online hotel bookings". Hospitality Review, 30 (1): 73-91.

Kotler, Philip. 2009. The Marketing of Nations. The Free Press: New York.

Kotler, P., and Keller, K.L. 2012. Manajemen Pemasaran, Edisi 113, Jilid I, Indeks. Jakarta.

Kurtz, D.L., and Clow, K.E. 1998. Service Marketing. New York: Wiley and Sons.

Lee, H. A., Guillet, B. D., and Law, R. 2012. "An examination of the relationship between online travel agents and hotels : A case study of choice hotels international and expedia.com." Focus on Information Technology, 54 (1): 95-107.

Lee, G.G and Lin, H.F. 2011. "Customer perception of e-service quality in online shopping". International Journal of Retail and Distribution Management. 33 (2): 161-176.

Liu, T.H. 2012. "Effect of E-service Quality on Customer Online Repurchase Intention". Lynn University. 
ISSN Cetak : 2087-0434

E-ISSN $\quad: 2599-0810$

Litvin, S.W., Goldsmith, R.E. and Pan, B. 2008. "Electronic word-of-mouth in hospitality and tourism management". Tourism Management, 29 (3): 458-468.

Lupiyoadi, R. 2001. Manajemen Pemasaran Jasa. Jakarta: Salemba Empat.

Matute, J., Polo-Redondo, Y., and Utrillas, A. 2016. "The influence of EWOM characteristics online repurchase intention: Mediating roles of trust and perceived usefulness". Online Information Review, 40 (7): 1090-1110, https://doi.org/10.1108/OIR-11-2015-0373.

Moningka and Loindong. 2016. "Service quality and customer loyalty in the commercial airline industry". Journal of Travel Research, 35: 50-65.

Oliver, R. L. 1997. Satisfaction: A Behaviourial Perspective On The Consumer. New York: McGrawrHill Companies, Inc.

Parastanti, G.P., Srikandi, K., dan Kadarisman, H. 2014. "Pengaruh Prior Online Purchase experience terhadap Trust dan Online Repurchase Intention. Jurnal Administrasi Bisnis (JAB), 16 (1):1-7.

Ribbink, D., van Riel, A.C.R., Liljander, V., and Streukens, S. 2004. "Comfort your online customer: quality, trust, and loyalty on the internet'. Managing Service Quality, 14 (6): 446-456.

Sabiote, Carmen M., Dolores M.F., J. Alberto Castaneda. 2012. "E-service quality as antecedent to e-satisfaction The moderating effect of culture". Online Information Review Vol. 36 No. 2.

Sen, S., and Lerman, D. 2007. Why are you telling me this? An examination into negative consumers reviews on the web". Journal of Interactive Marketing, 21 (4): 76-94.

Solimun. 2013. Structural Equation Modeling Lisrel dan Amos. Malang: Fakultas MIPA Universitas Brawijaya.

Swaid, S. I. and Wigand, R. T. 2007. "Key dimensions of e-commerce service quality and its relationships to satisfaction and loyalty". 20th Bled e-Conference e-Mergence: Merging and Emerging Technologies, Processes, and Institutions, Bled-Slovenia.

Wang. Y., Lo, H.P., and Hui, Y.V. 2003. "The antecedents of service quality and product quality and their lnfluences on bank reputation: Evidence from the banking industry in China". Managing Service Quality: An International Journal,13 (1): $72-83$.

Zeng. F., Hu, Z., Chen, R. and Yang, Z. 2009. "Determinants of online service satisfaction and their impacts on behavioral intentions". Total Quality Management and Business Excellence, 20 (9): 953-969.

Zeithmal, V.A., and Bitner, M.J 2006. Service Marketing (4th ed.). New York : McGraw Hill, International Edition 


ISSN Cetak : : 2087-0434

E-ISSN $\quad: 2599-0810$

Zeithaml, V.A., M.J. Bitner, D.D. Gremler. 2013. Services Marketing: Integrating Customer Focus Across the Firm 6 thed. Mc.Graw-Hill. Boston.

Zhang, K. Z. K., Hu, B., and Zhao, S. J. 2012. "How Online Social Interactions Affect Consumers Impulse Purchase on Group Shopping Websites?". Proceedings - Pacific Asia Conference on Information Systems, PACIS 2014, 81-98.

Zhou, T., Lu, Y., and Wang, B. 2009. "The relative importance of website design quality and service quality in determining consumers' online repurchase behavior." Information Systems Management, 26 (4): 327-337. DOI: 10.1080/10580530903245663. 